\title{
Can Lawyers Solve the Problems of the Tort System?
}

\author{
Richard A. Posner $\dagger$
}

The editors have asked me to comment on Professor Howard Latin's Article in this Symposium, ${ }^{1}$ I suppose because they regard the Article as a challenge to views with which I am associated. It is that, for Professor Latin basically asserts the irrelevance of the economic model of human behavior to explaining the behavior of individuals faced with hazards to their health or safety; but having read and reflected on his article, I am not persuaded to abandon my approach for his.

I shall begin not at the beginning of his long article, but with its mam concrete proposal, which is to make automobile manufacturers strictly liable in tort for personal injuries resulting from automobile accidents-whether or not the automobile is defective. ${ }^{2}$ This is an astounding suggestion. Some 50,000 people die every year in auto accidents in the Umited States, and the average value of a life for tort purposes must be a milhon dollars by now. Professor Latin's proposal implies subjectmg the automobile industry to a new tort hability of some $\$ 50$ billion for death cases alone, ${ }^{3}$ and probably an equal or greater amount for nonfatal injuries and for property damage-unless Professor Latin is right that most of these harms can be avoided, and cheaply too, by air bags, or "puncture-resistant gas tanks," or better brakes and steering mechanisms, or other safety apphiances. Automobile prices probably would skyrocket, though automobile liability and accident insurance rates would fall.

But I am interested less in the proposal than in the reason for it, and less in the reason than in what it tells us about a certain type of legal scholarship. Professor Latin has persuaded himself that enterprises are so much more likely than individuals to respond to legal rules regulating safety that they ought to be made liable for all, or almost all, accidents in which they are involved. He has persuaded himself of this proposition not by scientific study of how enterprises and individuals respond to legal

$\dagger$ Judge, United States Court of Appeals for the Seventh Circuit; Senior Lecturer, University of Chicago School of Law. A.B. 1959, Yale College; LL.B. 1962, Harvard University. I am grateful to William Landes, Richard Levy, and Helane Morrison for helpful comments on a previous draft. (1985).

1. Latin, Problem-Solving Behavior and Theories of Tort Liability, 73 CALIF. L. REv. 677

2. Id. at 726-29; see also id. at $689-92$.

3. Id. at 691. Professor Latin says billions and leaves it at that. 
rules, but by intuition reinforced by a rather casual empiricism. The government estimates that air bags would save many lives, yet the auto manufacturers won't install tliem unless forced to do so, because consumers don't want to pay the cost. ${ }^{4}$ So Professor Latin, who believes these consumers to be sliort-sighted, proposes to induce the manufacturers to install air bags anyway, by making them liable for all the lives lost in auto accidents, ${ }^{5}$ and even, perhaps, for lives lost when people drive into bridge abutments or when drunks run down pedestrians. Maybe he would not go quite so far. He reserves the question of drunk driving, and in anotlier part of the article says that he would not make the manufacturer of a knife liable to someone who cut liimself while using it as a tootlipick. $^{6}$ On the other hand, lie is inclined to make the manufacturer of airplane glue liable to people who are imjured sniffing it to get high, because that misuse of the product is foreseeable; ${ }^{7}$ and it is equally foreseeable to a maufacturer of automobiles that some of the people who drive its cars will be drunk. Thus, the logic of his argument points to making the automobile manufacturer liable for drunk-driving accidents, too.

What are we to call legal scholarslip that comes up with proposals of this sort, on grounds of this sort? It is not legal-doctrinal scholarship. Althougl1 Professor Latin cites cases, he is not interested in exploring the relations between cases, discovering the hidden rationales of legal rules, or finding new patterns; the cases merely illustrate his thesis that organizations are more responsive tlian individuals to the incentives created by tort liability. The article is not economic analysis, eitler; it does not use economics consistently or systematically. For exainple, while acutely sensitive-perliaps hypersensitive--to the infornation costs of individual consumers or drivers in making safety clioices, Professor Latin is insensitive to information and agency costs within organizations. ${ }^{8}$ Tlose costs, lowever, might impair, or even obliterate, the transmission of safety directives within the organization. Such costs have to be compared with the information costs of drivers, consuners, etc., in trying to avoid accidents by complying with norms of tort law. Professor Latin does not make this comparison, and, as we shall see, he ignores evidence that nonorganization man is a more efficient accident preventer than he believes.

4. Many consumers are afraid of air bags, since when the bag fills with air, the driver loses control of the car.

5. Latin, supra note 1, at 691-92. Latin assumes the cost of the air bags will be less than the benefits to the auto manufacturers in reduced tort damages.

6. Id. at 732 n.235.

7. Id. at 713 .

8. Yet those costs have long been a particular concern of Professor Latin's favorite economists, such as Herbert Simon and Oliver Williamson. 
Professor Latin also does not have a firm grip on the concept of externality, which is, or should be, fundamental to any analysis of safety regulation. It is one thing to force people to take account of the costs that they impose on unwilling others. Such "external" costs are a traditional and relatively uncontroversial concern of public policy. It is another and more dubious thing to force people to protect themselves. Paternalistic rationales are controversial. Thus the air bag, which protects only the occupant and not the victims of his carelessness (except the front-seat passenger, if there is one)-which indeed may endanger others ${ }^{9}$-is a less appropriate focus of public-policy concern than inadequate brakes or steering mechanisms. But they are all one to Professor Latin. He says, moreover, that high insurance premiums for risky drivers may lead them to buy cheaper and smaller cars in order to keep down their driving costs, but that this won't increase safety, because small cars are more vulnerable in crashes. ${ }^{10} \mathrm{He}$ is wrong; safety will be increased. A pedestrian or another driver is likely to suffer less severe injuries if hit by a small car than a large one. This is all to the good; and since a driver is more vulnerable in a small car, he may drive more safely-all the better. And notice how in pointing out that tort liability may increase the demand for smaller cars, Professor Latin has unwittingly made a point against his thesis that liability does not affect individuals' behavior. This is also true if (as he speculates) high liability insurance premiums deter some people from driving cars altogether, and induce them to substitute motorcycling or hitchhiking. Professor Latin says that hitchhiking and motorcycling are dangerous. ${ }^{11}$ But a hitchhiker does not create a safety risk to anyone else, and a motorcyclist creates less danger to others than does an automobile driver. So the external costs of highway accidents will be reduced if liability insurance rates induce some automobile drivers to become hitchhikers or motorcyclists.

Professor Latin's most serious economic error involves his refusal to take seriously economic studies that find that individuals-specifically, automobile drivers-do respond to legal rules. These studies show that liability insurance premiums affect the decision to drive, ${ }^{12}$ that the number of automobile deaths has risen as a result of the no-fault movement (perhaps by as much as $15 \%$ in some states), ${ }^{13}$ and that safety-belt requirements increase the number of pedestrian deaths because people

9. See infra note 14 and accompanying text.

10. Latin, supra note 1 , at 728.

11. Id.

12. See R. Grayston, Deterrence in Automobile Liability Insurance (unpublished Plı.D. thesis, University of Clicago Graduate School of Business 1971).

13. See Landes, Insurance, Liability, and Accidents: A Theoretical and Empirical Investigation of the Effect of No-Fault Accidents, 25 J.L. \& EcoN. 49, 50 (1982). 
who feel safer drive faster. ${ }^{14}$ The first two studies are the most pertinent, because they show that the consequences of liability (or nonliability), though pecuniary, affect safety behavior. The third suggests, consistently, that people make rational tradeoffs in the face of danger.

There is a contrary hiterature in psychology, to which Professor Latin refers. But he is not entitled simply to dismiss the economic studies, as he does, on the sole ground that they rest on unrealistic premises about huinan behavior.

The fact that some decisionmaking undoubtedly occurs on the unconscious level im no way suggests that people can achieve optimal unconscious choices. Unless the unconscious mind is omniscient, possesses infinite computational and attentional capacities, and is free from cognitive biases, unconscious decisionmaking could not possibly achieve maximizing results in all cases. To put it another way, there is no evidence and no reason to presuine that the unconscious mind is superhuman ${ }^{15}$

This passage reveals a fundamental misconception about the economic approach to human behavior: that its vahidity depends on the unrealistic assumption that people have superhuman mental qualities. This is a common misconception of lawyers and is worth taking a moment to try to dispel.

Economic models frequently are built from unrealistic assumptions. For example, the conventional model of perfect competition assumes a market that consists of an extremely large number of small firms making the identical product. It assumes that no firm can affect the market price by altering its own output and that neither buyers nor sellers have any search costs. These assumptions commonly are false. Nevertheless, the model is quite good at predicting things like the response of the price of cigarettes or gasoline to the imposition of an excise tax. More refined

14. See Peltzman, The Effects of Automobile Safety Regulation, 83 J. PoL. ECON. 677 (1975). Many other economic studies, which Professor Latin does not refer to, also find that people behave rationally in response to dangers to health and safety. See, e.g., Dardis, The Value of a Life: New Evidence from the Marketplace, 70 AM. ECON. REv. 1077 (1980); Olson, An Analysis of Wage Differentials Received by Workers on Dangerous Jobs, 16 J. HuMAN RESOURCES 167 (1981); Sehneider, Klein \& Murphy, Governmental Regulation of Cigarette Health Information, 24 J.L. \& ECON. 575 (1981); Thaler \& Rosen, The Value of Saving a Life: Evidence from the Labor Market, in HousEhold Production and Consumption 265 (N. Terleckyj ed. 1975). There is also economic evidence that Professor Latin might have cited, but does not, suggesting that, as he believes, people do Imderestimate the benefits of safety devices-specifically, of seat belts. See Arnould \& Grabowski, Auto Safety Regulation: An Analysis of Market Failure, 12 BELL J. ECON. 27 (1981).

Incidentally, Professor Latin is wrong to use neghigence cases as evidence that people are irrational; the accidents that the law of negligence fails to deter are a biased sample of behavior toward safety. He might as well say that the criminal law does not deter, because we observe crimes being committed. Yet there is much evidence that it does deter. For a review of the literature, see $D$. Pyle, The Economics of Crime and Law Enforcement ch. 3 (1983). It does not deter perfectly, but that is because the costs of criminal sanctions are so high. See Posner, An Economic Theory of Criminal Law, (forthcoming in the Columbia Law Review, October 1985).

15. Latin, supra note 1 , at 685 n.46. (emphasis in original). 
models may yield even better predictions, ${ }^{16}$ but the simple, unrealistic model does quite well. ${ }^{17}$ This is possible because the builders of economic models, for the sake of simplicity or logical rigor, often make more demands on reality than they have to. It cannot be proved mathematically that a firm will be a price-taker (i.e., cannot alter the market price by changing its output), unless the number of firms in the market is infinite. As a matter of fact, though, a firm may be a price-taker when there are only ten firms in the market-maybe only two, or if entry into the market is sufficiently easy, one. Similarly, economic studies of beliavior which implicitly assume, unrealistically, that the consumer "possesses infinite computational and attentional capacities" may still predict correctly how consumers will respond to incentives created by a seat-belt law, or by no-fault automobile compensation plans, or by liability insurance rates. Professor Latin is oblivious to this possibility, which is why he thinks it enough to point out that the economic studies.rest on unrealistic assumptions about the human mind, and to pass on.

I do not wish to be understood as denying tliat people frequently are inattentive, ignorant about the law and about accident probabilities, hopelessly clumsy, and so fortl, and that these things blunt the effectiveness of tort law as a deterrent to careless behavior. ${ }^{18}$ As a matter of fact, these points play an important role in the positive economic theory of tort law. ${ }^{19}$ But granted that tort law is a clumsy system of social control in many of the areas that Professor Latin is concerned with, the studies I have cited, particularly the Grayston and Landes studies, suggest that it is far from totally mefficacious. And all of the alternatives, including the massive reconstitution of tort law proposed by Professor Latin, are bound to liave very serious problems of implementation and efficacy of their own. Hence, pointing out the obvious failings of the present tort system is not very constructive. I repeat that if people are as irrational as Professor Latin believes, shifting liability from individuals to organizations-which are simply groups of mdividuals-is unlikely to reduce the costs of accidents by much, if anything.

I have said that what Professor Latin's article offers us is neither legal-doctrinal scholarship nor econoinic scholarship. I add that it is not empirical scholarship. Professor Latin's favorite source of empirical data

16. See, e.g., Barzel, An Alternative Approach to the Analysis of Taxation, 84 J. PoL. EcoN. 1177 (1976).

17. For an interesting illustration of this point, see J. HiRshle1FER, PRICE ThEORY AND APPLications 419-20 (3d ed. 1984).

18. It is worth noting, however, that it is fallacious to think that hability insurance per se "externalizes" the costs of accidents; the insured has to pay the insurance coinpany to share the risk.

19. See, e.g., Landes \& Posner, A Positive Economic Analysis of Products Liability, (forthcoming in the Journal of Law and Economics, 1985); Landes \& Posner, The Positive Economic Theory of Tort Law, 15 GA. L. REv. 851, 874-76, 878-80 (1981). 
is the New York Times; another favorite is the Federal Register. These sources do not provide firm foundations for multibillion-dollar proposals for legal change. Professor Latim gives the reader no sense of what the empirical literature, economic or otherwise, ${ }^{20}$ can tell us about the costs and benefits of so radical a restructuring of the law. His article is not an engineering study, either, despite the references to "puncture-resistant gas tanks," air bags, and other safety devices. Nor is his article a legislative study along the hines of the influential Keeton-O'Connell book on no-fault, ${ }^{21}$ for Professor Latin does not present his proposals in any detail or explain how and by whom they might actually be put into effect. His criticism of Professor Calabresi can be turned against himself: he "seldom addresses realistic implementation constraints and seldom provides concrete illustrations where all relevant considerations are balanced."22 Only for "seldom" we might substitute "never."

It seems to me that the day is past when a law professor could ask for serious consideration of a proposal for radical legal change based on his intuitions about what is after all an empirical, a policy, an economic, a legislative question, but not a question of law. I am sure that Professor Latin has a fine command of tort law and could contribute greatly to that complex field by using his legal skills to illuminate tort doctrine. And if he followed the economic approach more closely he might be able to contribute to the burgeoning economic analyses of tort law and accident problems. But he first must free himself of the misconceptions that economics does not "work" in the presence of positive information costs, that organizations have perfect control over their agents and employees, that definite costs always outweigh indefinite benefits, ${ }^{23}$ that it is anomalous for economists to "be unwilling to accept people's opinions that their own choices often do not maximize personal welfare,"24 and that

20. See, e.g., A. Conard, J. Morgan, R. Pratt, C. Voltz \& R. Bombaugh, Automobile Accident Costs and Payments (1964); H.L. Ross, Settled Out of Court: The Soclal Process of Insurance Claims Adjustment (rev. 2d ed. 1980).

21. See R. KeEton \& J. O'CONNEl, BASIC Prótection fOR THE TRAFFic Victim (1965).

22. Latin, supra note 1 , at 718 n.179.

23. See id. at 682-96. "[W]e have ample evidence about the high costs of the torts system, while the deterrent value of legal rules is speculative in risk contexts where typical parties are not effective problem solvers." Id. at 696. Consider a substitution for that assertion: "We have ample evidence about the high costs of pollution control while the benefits of pollution control are speculative in inost contexts." If one made such a substitution, Professor Latin would be-rightly-horrified, though the stateinent would then be even more aceurate.

24. Id. at 685 n.45. Professor Latin appears to believe, inconsistently as it seems to me, both that people's conscious assessments of their motives should be accepted at face value and that the Freudian theory of the unconscious is true. He is very free with speculation about human behavior. He thinks it apparent, for example, that tort rules will not affect the behavior of a person whose pet aminal is in danger. I do not understand his theory of human behavior. Further complicating the picture is the fact that Professor Latin harbors the common misconception that rationality presupposes consciousness, so that unless people think they are coinparing the costs and benefits of alternative courses of action, they are not being rational, whatever their objective behavior may suggest. 
social insurance is unproblematic. Professor Latin might even be able to contribute to economics, by reconstructing-and then testing-a more realistic model of human behavior toward danger than one that abstracts from information costs. He has not done that; he provides no data to counter the economic evidence that he so summarily dismisses. His article seems to ine to occupy an uneasy middle area between law and science, to be a kind of rootless policy analysis that $I$ do not find convincing when used as a basis for proposing radical changes in law-to be "inultidisciplinary" in an unsatisfactory sense. ${ }^{25}$

I sliall end with two of Professor Latin's specific examples that have a special interest to students of tort law-and the second, to any redblooded American as well. The first is the famous Vincent case, where the owner of a pier was allowed to recover from a shipowner the damages that the ship had caused to the pier during a storm. ${ }^{26}$ The damage could liave been avoided if the ship had cast off from the pier, but then the slip might have been lost, and the loss would have been greater than the damage to the pier. Professor Latin thinks there should be no liability in such a case, because the parties liave equal knowledge of the risks, im contrast to what he conceives to be the situation between an auto manufacturer and a driver. I disagree, and think the case riglttly decided. The owner of the pier rendered tlie shipowner a valuable service, for which ordimarily lie would as a businessman expect to be paid. It seems at a minimum lie should be compensated for out-of-pocket costs in rendering the service. $^{27}$

The second example is Professor Latm's proposal that the owners of baseball and otler athletic stadiuns be strictly liable to any spectator hit by a ball, or injured while scrainbling for a ball, or beaten up by a drunk, or otherwise injured at the game. This seems to ine a particularly doctrinaire application of his thesis. Even without the sanctions of tort law, the stadium owner has every incentive to optimize tlie safety of tlie spectators in order to maximize ticket price and attendance. The dangers are hardly concealed and for the most part are best prevented by the potential victims themselves. It seems to me fantastic to suppose that if Professor Latin's proposal is adopted stadium owners will put a net in front of all the spectators or impose a sobriety test on spectators who drink beer. Strict liability will just be a form of compulsory insurance. There

But rationality as the word is used by economists is an external standard, so that it is no solecism to speak of a rational frog or a rational pigeon.

25. Picking and choosing among and within the disciplines is not multidisciplinary scholarship. To call Herbert Simon "the Nobel laureate economist" and "an influential theorist," and George Stigler a "Chicago economist," is I suppose what Professor Latin would call a Freudian ship.

26. Vincent v. Lake Erie Transp. Co., 109 Minn. 456, 124 N.W. 221 (1910).

27. See Landes \& Posner, Salvors, Finders, Good Samaritans, and Other Rescuers: An Economic Study of Law and Altruism, 7 J. LEGAL STUD. 83, 113 (1978). 
is also a killjoy quality about the suggestion which should not go unnoticed and which provides an appropriate coda to my lament. 